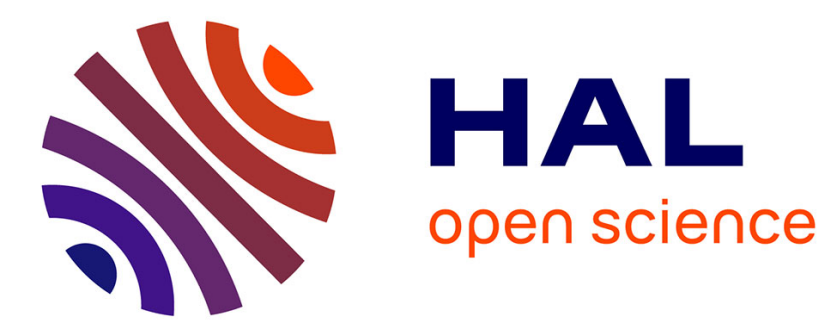

\title{
The effect of alloy content on the microstructure of as-deposited weldmetal in 9Cr-based ferrous weldments
}

R. Haigh, M. Strangwood

\section{To cite this version:}

R. Haigh, M. Strangwood. The effect of alloy content on the microstructure of as-deposited weldmetal in 9Cr-based ferrous weldments. Journal de Physique IV Proceedings, 1993, 03 (C7), pp.C7-131-C7134. 10.1051/jp4:1993720 . jpa-00251833

\section{HAL Id: jpa-00251833 https://hal.science/jpa-00251833}

Submitted on 1 Jan 1993

HAL is a multi-disciplinary open access archive for the deposit and dissemination of scientific research documents, whether they are published or not. The documents may come from teaching and research institutions in France or abroad, or from public or private research centers.
L'archive ouverte pluridisciplinaire HAL, est destinée au dépôt et à la diffusion de documents scientifiques de niveau recherche, publiés ou non, émanant des établissements d'enseignement et de recherche français ou étrangers, des laboratoires publics ou privés. 


\title{
The effect of alloy content on the microstructure of as-deposited weldmetal in 9Cr-based ferrous weldments
}

\author{
R.H. HAIGH and M. STRANGWOOD
}

School of Metallurgy and Materials, The University of Birmingham, Elms Road, Edgbaston, Birmingham B15 2TT, U.K.

\begin{abstract}
The more widespread use of $9 \mathrm{Cr}-1 \mathrm{Mo}$-based steels (modified and un-modified) is limited, in part, by a lack of understanding of the welding behaviour of this class of materials. A series of weldments, based on modified $9 \mathrm{Cr}-1 \mathrm{Mo}$ alloy steels, with varying $\mathrm{Si}$ and $\mathrm{Mn}$ contents was investigated using transmission electron microscopy (TEM). All as-deposited samples were found to consist of laths of heavily dislocated martensite separated by an interlath phase. Addition of $\mathrm{Si}$ was found to increase the amount of retained austenite $(\gamma)$ present in the interlath region, whilst increasing $\mathrm{Mn}$ content promoted carbide formation. At high levels of both additions, a banded structure containing both phases was formed. These additions had little effect on the carbides $\left(\mathrm{M}_{23} \mathrm{C}_{6}\right.$ type) present within the laths.
\end{abstract}

\section{Introduction}

Steels based on 9Cr-1Mo alloy additions have been developed for high temperature service in petrochemical and nuclear plant. These alloys exhibit high proof stress, good resistance to stress corrosion cracking, and high rupture creep strength generally, giving some advantages over type 304 stainless steel at temperatures up to $625^{\circ} \mathrm{C}$ [1]. The $9 \mathrm{Cr}-1 \mathrm{Mo}$ grades are air-hardenable and give a fully martensitic structure, which, on tempering, can give carbide precipitation. The good creep properties of this alloy, in the normalised and tempered condition, have been attributed to the presence of carbide particles and a tangled dislocation substructure, from the displacive transformation. Modification of this alloy, by the addition of small quantities of $\mathrm{Nb}$ and $\mathrm{V}$ (typically $0.2 \mathrm{wt} \% \mathrm{~V}, 0.08 \mathrm{wt} \% \mathrm{Nb}$ ) maintains stability and creep strength up to temperatures of $704{ }^{\circ} \mathrm{C}$ compared with $600^{\circ} \mathrm{C}$ for the unmodified alloy [2]. These additions promote the formation, during tempering, of finely dispersed $(\mathrm{Nb}, \mathrm{V})$ carbides and carbomitrides less than $1 \mu \mathrm{m}$ in size. In addition, coarse $\mathrm{M}_{23} \mathrm{C}_{6}$ carbides are expected to form, usually less than $0.5 \mu \mathrm{m}$ in diameter, and containing $\mathrm{Cr}, \mathrm{Fe}, \mathrm{V}, \mathrm{Mo}^{[3]}$. The presence of slower diffusing alloy elements means that tempering temperatures above $500^{\circ} \mathrm{C}$ are required. The rapid thermal cycle experienced during welding causes microstructural modification of the as-deposited and heat affected regions. The large number of variables involved in the welding process, e.g. chemical composition, electrode type, current and voltage, have made quantitative work on the effects of these factors on weld properties difficult and time consuming. This has led to an inability to predict the structure of the welds and to optimise the welding procedures for a range of conditions. Welding procedures have been based on empirical guidelines, largely for thin section 
pipework, with little real understanding of the role of each factor. Greater understanding is required if the range of compositions and joint geometries are to be expanded.

A major influence on the properties of the joint will be the microstructure within the as-deposited region, and the heat affected zone (HAZ). The size, distribution and types of the phases present, e.g. carbides, martensite laths, $\delta$-ferrite and retained austenite, within the as-deposited region will be determined by the composition of the baseplate, welding parameters, thermal cycle, electrodes and joint geometry. Currently, TIG/MIG processes are used for $9 \mathrm{Cr}-1 \mathrm{Mo}$ pipework, but, as thicker sections are considered, higher heat input processes will be needed. Hence the microstructures developed in the weldmetal and HAZ of a series of manual metal arc (MMA) weldments with controlled alloying levels are being investigated. Initially the roles of the deoxidising agents $\mathrm{Si}$ and $\mathrm{Mn}$ are being assessed, and this work concentrates on the as-deposited weldmetal.

\section{ExperimentaI}

As-deposited weldments were provided by Dr G.M.Evans, having been prepared as detailed below. $4 \mathrm{~mm}$ diameter electrodes were produced to provide two levels of manganese (1.1 and 0.7 wt $\%)$ and two levels of silicon ( 0.35 and $0.15 \mathrm{wt} \%)$ as shown in Table 1 . Three beads per layer were deposited at $1 \mathrm{~kJ} / \mathrm{mm}$ and the interpass temperature was $175^{\circ} \mathrm{C}$. A total of 18 passes were made. Slices, $0.5 \mathrm{~mm}$ thick, were removed from the topmost, as-deposited weldrun and prepared for transmission electron microscopy (TEM) by mechanical grinding to $100 \mu \mathrm{m}$ followed by electropolishing in a solution of $10 \%$ perchloric acid in methanol at $15 \mathrm{~V}$ and $-27^{\circ} \mathrm{C}$. The foils were examined in a Phillips CM20 TEM operating at $200 \mathrm{kV}$.

Table 1: Weldmetal composition

\begin{tabular}{|c|c|c|c|c|c|c|c|c|c|}
\hline & $\mathrm{C}$ & $\mathrm{Mn}$ & $\mathrm{Si}$ & $\mathrm{Cr}$ & $\mathrm{Mo}$ & $\mathrm{Al}$ & $\mathrm{Ti}$ & $\mathrm{O}$ & $\mathrm{N}$ \\
\cline { 2 - 10 } & \multicolumn{6}{|c|}{$\mathrm{Wt}$} & $\%$ & \multicolumn{5}{c|}{ ppm } \\
\hline $\mathrm{MnSi}$ & 0.093 & 1.06 & 0.36 & 9.10 & 1.03 & 9 & 27 & 530 & 460 \\
\hline $\mathrm{Mn}$ & 0.097 & 1.04 & 0.16 & 9.20 & 1.06 & 7 & 19 & 750 & 430 \\
\hline $\mathrm{Si}$ & 0.097 & 0.67 & 0.34 & 9.10 & 1.04 & 9 & 29 & 580 & 460 \\
\hline- & 0.088 & 0.65 & 0.16 & 8.83 & 1.12 & 6 & 16 & 800 & 430 \\
\hline
\end{tabular}

\section{Results}

In all samples the microstructure consisted of martensite laths with a thin interlath region. $\delta$ ferrite was observed during optical examination of the high silicon samples, but this phase was not observed in TEM foils from this specimen. The interlath phase in the weldment containing low levels of both $\mathrm{Mn}$ and $\mathrm{Si}$ was found to consist mainly of $\gamma$ with some carbides (of type $\mathrm{M}_{23} \mathrm{C}_{6}$ ) present. The width of laths was in the range 0.47-0.61 $\mu \mathrm{m}$. Addition of Si to the alloy reduced the tendency towards carbide formation in the interlath region, although similar carbide populations were observed in the martensite laths. The opposite trends were noted for the weldmetal with high $\mathrm{Mn}$ and low Si levels, where the interlath phase was composed entirely of $\mathrm{M}_{23} \mathrm{C}_{6}$ carbide. With high levels of both $\mathrm{Mn}$ and $\mathrm{Si}$, a mixed interlath structure of $\gamma$ and $\mathrm{M}_{23} \mathrm{C}_{6}$ was observed with the retained $\gamma$ being banded by a layer of $\mathrm{M}_{23} \mathrm{C}_{6}$ (Figure 1.) For all the compositions studied, the laths were composed of highly dislocated martensite, within which $\mathrm{M}_{23} \mathrm{C}_{6}$ was present. These carbides interacted strongly with transformation dislocation. No significant variations were noted in the size, distribution or nature of these carbides with alloying. 
The carbides were disc-like, $0.09-0.11 \mu \mathrm{m}$ in diameter and arranged in three variants of one orientation, suggesting an autotempered origin (Figure 2).

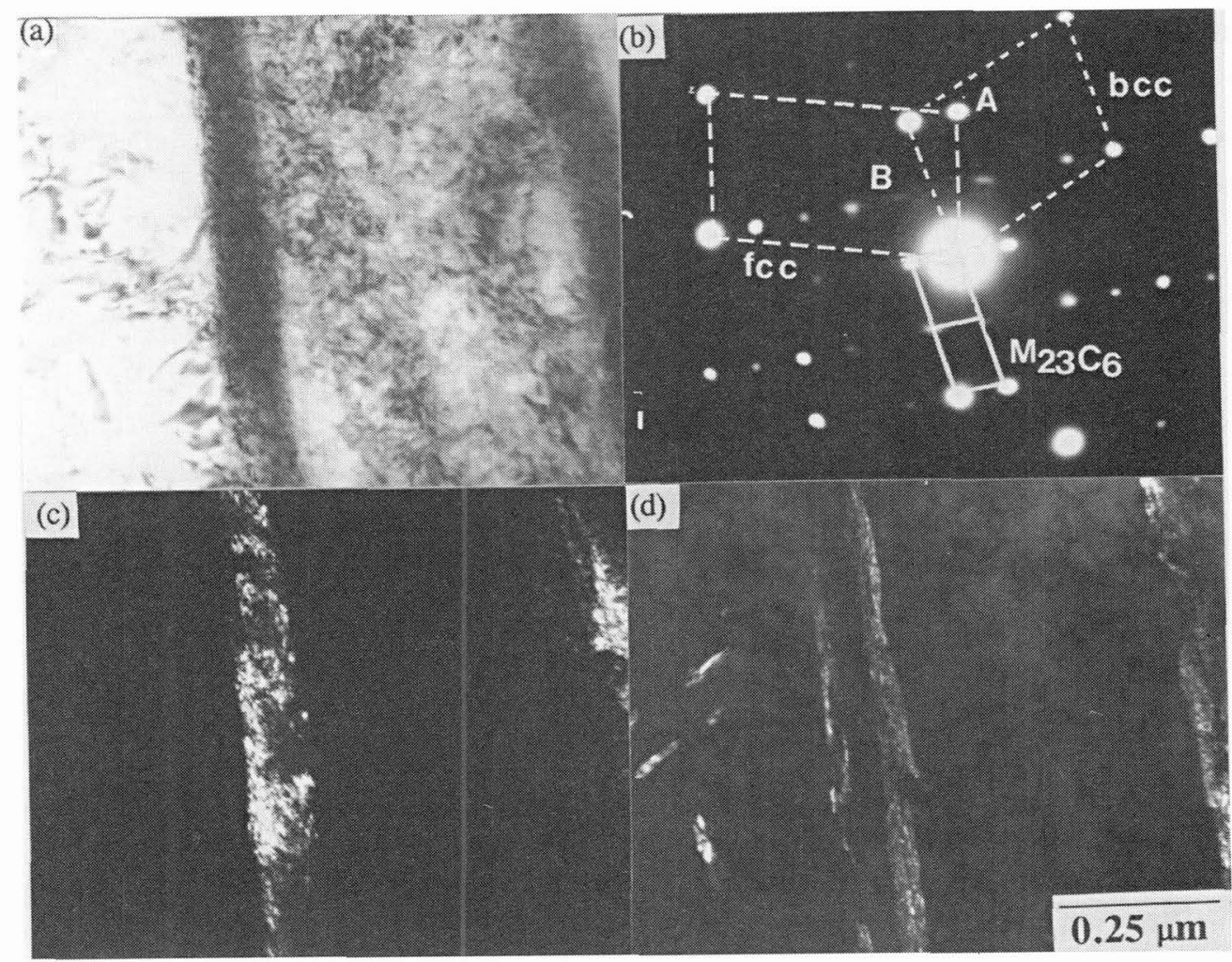

Figure 1. Lath/interlath region in weldment with high levels of $\mathrm{Si}$ and $\mathrm{Mn}$, (a) bright field image, (b) selected area diffraction patterns from martensite (bcc), austenite (fcc) and $\mathbf{M}_{23} \mathrm{C}_{6}$, (c) austenite dark field image from spot A, and (d) carbide dark field image from spot B.

Deoxidation was achieved largely by $\mathrm{Si}$ and the inclusions noted in all specimens were manganese alumino-silicates containing $\mathrm{Ti}$. The presence of these deoxidation products appeared to exert little influence over the as-deposited microstructure. As in lower alloy steels, $\mathrm{Si}$ acts to reduce the tendency for carbide formation, but largely at the lath boundaries, suggesting segregation of alloying elements to those sites during the welding cycle. With low additions of $\mathrm{Mn}$ and $\mathrm{Si}, \mathrm{C}$ and $\mathrm{Cr}$ partition to the boundaries leads to precipitation of $\mathrm{M}_{23} \mathrm{C}_{6}$ with some retained $\gamma$. As Si is increased, partition to the interlath regions gives sufficient $\mathrm{C}$ in solution that the entire interlath phase is $\gamma$. With enhanced $\mathrm{Mn}$ levels (low $\mathrm{Si}$ additions), the formation of carbides is promoted so that the stability of $\gamma$ is reduced leading to a fully carbide interlath layer. At high levels of both additions a mixed interlath is observed again where the presence of Si stabilises $\gamma$. However, towards the edge of the interlath region, where segregated $\mathrm{Si}$ and $\mathrm{C}$ levels decrease, carbide formation is again evident. Elimination of $\mathrm{Si}$ from un-modified $9 \mathrm{Cr}$ has been found to suppress precipitation of Laves phase $\mathrm{Fe}_{2} \mathrm{Mo}$, resulting in improvements in toughness ${ }^{[4]}$ and the presence of both $\delta$-ferrite and retained $\gamma$ in as-deposited weldmetal may cause microstructural instability and deleterious mechanical properties in service. Therefore silicon levels should be kept low and additional deoxidants such as $\mathrm{Al}$ or $\mathrm{Ti}$ are required. The presence of $\delta$-ferrite will lead to the 
partition of silicon to this region. This will reduce the amount of silicon within the rest of the matrix, and so will reduce its effect. The microstructural consequences of the presence of $\delta$ ferrite is being investigated. The multicomponent segregation behaviour of $\mathrm{Si}, \mathrm{C}, \mathrm{Cr}$ and $\mathrm{Mn}$ is also being investigated to predict the local chemistry and the susceptibility of the microstructure to $\gamma$ retention both with and without interlath carbides.
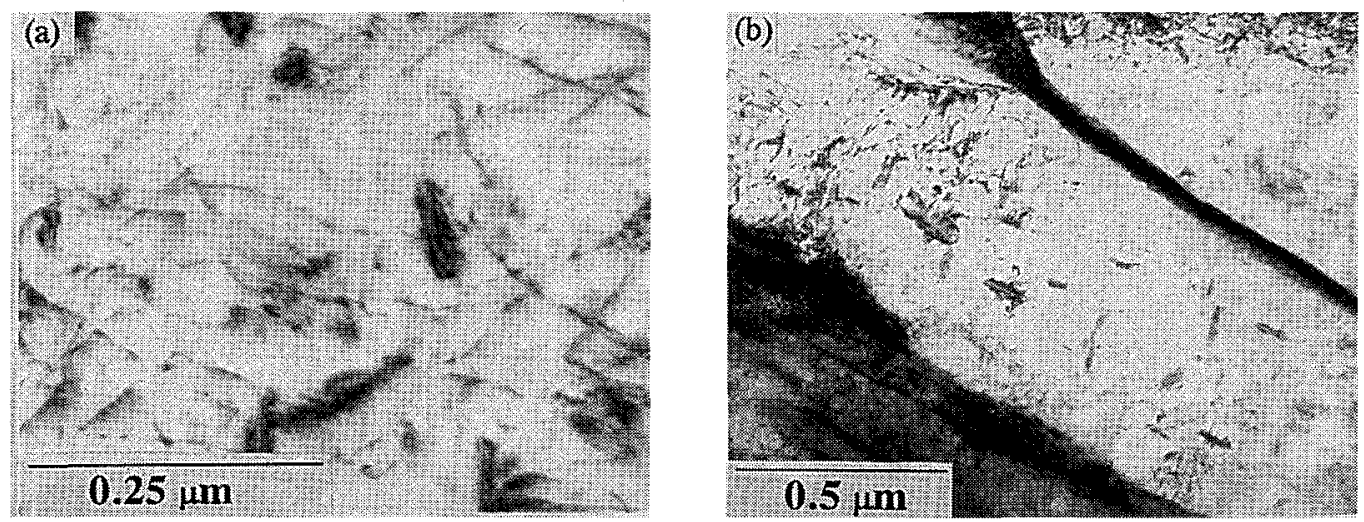

Figure 2. Disc-like carbides interacting with transformation dislocations within martensite for welds containing (a) low levels of both $\mathrm{Mn}$ and $\mathrm{Si}$, and (b) high Si only.

\section{Conclusions}

1. Autotempered $\mathrm{M}_{23} \mathrm{C}_{6}$ carbides in martensite laths are largely unaffected by $\mathrm{Si}$ and $\mathrm{Mn}$ variation

2. Si partitioned to the interlath regions retards carbide formation, thereby increasing the amount of $\mathrm{C}$ in solution and enhancing retention of $\gamma$ at these sites.

3. High levels of $\mathrm{Mn}$ increase the tendency to form $\mathbf{M}_{23} \mathrm{C}_{6}$-type carbides in the interlath regions.

4. Addition of both $\mathrm{Mn}$ and $\mathrm{Si}$ results in a multilayer interlath structure composed of $\gamma$ and $\mathrm{M}_{23} \mathrm{C}_{6}$.

5. Si-based deoxidation products do not influence microstructural development in as-deposited weldmetal.

\section{Acknowledgements}

The authors are grateful to Prof. J.F.Knott for the provision of laboratory facilities, to SERC for financial support (RHH) and to Dr G.M.Evans for material supply and helpful discussions.

\section{References}

1. JONES W.B., Proc. ASM International Conf. on Ferritic Steels for High Temperature Applications, Warrendale, PA, (1981).

2. BOOKER M.H., SIKKA V.K. and BOOKER B.L.P., Proc. ASM International Conf. on Ferritic Steels for High Temperature Applications, Warrendale, PA, (1981).

3. JONES W.B., HILLS C.R. and POLONIS D.H., Metall. Trans A 22, (1991), 1049.

4. HOSOI Y., KUNIMITSU S., URITA T. and WADE N., Journal of Nuclear Materials $\underline{143}$, (1986), 461. 